\title{
Phytophthora boehmeriae
}

\section{Overview}

Phytophthora boehmeriae Sawada is a species that has been recorded on only a few hosts (Erwin and Ribeiro 1996) since its first description in leaves of Boehmeria nivea (L.) Gaud-Beau in Taiwan (1927). It has also been reported in China, Australia, Greece (Erwin and Ribeiro 1996) and South Africa (Roux and Wingfield 1997). In South America, it was reported only in Argentina on citrus (Frezzi 1950), and in Brazil on black wattle (Santos et al. 2006). Erwin and Ribeiro (1996) report some additional trees as hosts: Deodar cedar (Cedrus deodora (G. Don) D. Don), eucalyptus (Eucalyptus pilularis Sm.) and Mexican yellow pine (Pinus patula Schiede ex Schlectendahl et Chamisso). In black wattle (Acacia mearnsii De Wild.), P. boehmeriae has been reported in South Africa (Roux and Wingfield 1997) and Brazil (Santos et al. 2006), thus becoming one of the causal agents of the disease known as gummosis, along with $P$. nicotianae (Santos et al. 2005), $P$. frigida (Alves et al. 2016) and P. meadii McRae (Roux and Wingfield 1997). Gummosis is the main disease of black wattle in Brazil (Santos et al., 2005) and South Africa (Roux and Wingfield 1997). It is characterized by necrotic lesions on the trunk, from the collar to the upper portions, with or without gum exudation (Santos and Luz 2007).

\section{Morphology}

Sporangia of $P$. boehmeriae are ovoid to spherical, papillate and caducous, measuring $35 \mu \mathrm{m} \times 30 \mu \mathrm{m}$, with a length:width ratio of 1.16:1, mean depth of papillae of $4.83 \mu \mathrm{m}$, and exit pore of $4.69 \mu \mathrm{m}$ (Fig. 1). P. boehmeriae is homothallic, forming plerotic oospores with smooth walls and amphigynous antheridia. Cultures produce oospores abundantly (Fig. 2). Chlamydospores are terminal or intercalary (Fig. 3) (Santos et al. 2006).

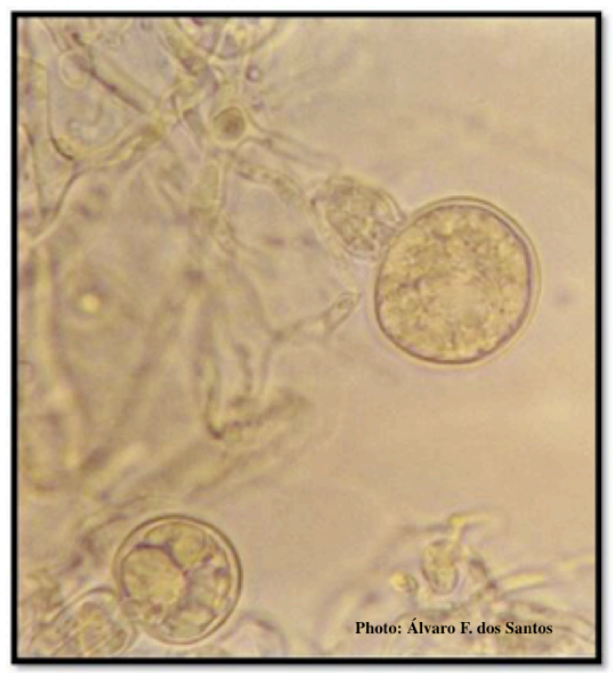

Figure 2. Oogonia and oospores with amphigynous antheridia. (reproduced with permission Summa Phytopathologica, courtesy A. F. dos Santos).

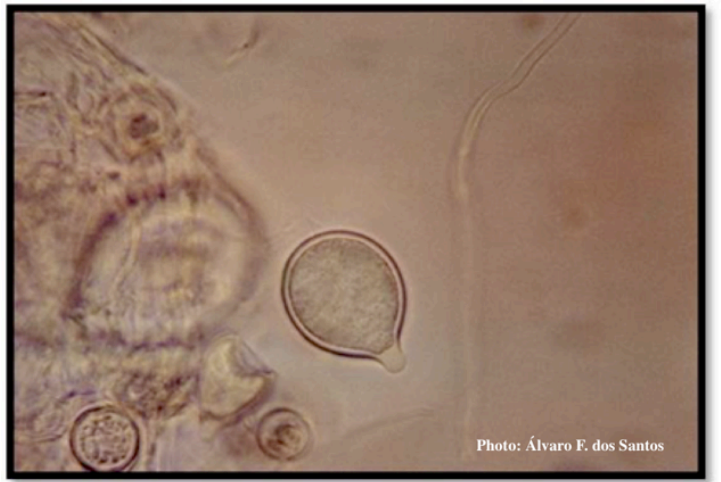

Figure 1. Sporangia showing ovoid and ovoid to spherical shape and papillate condition (reproduced with permission Summa Phytopathologica, courtesy A. F. dos Santos).

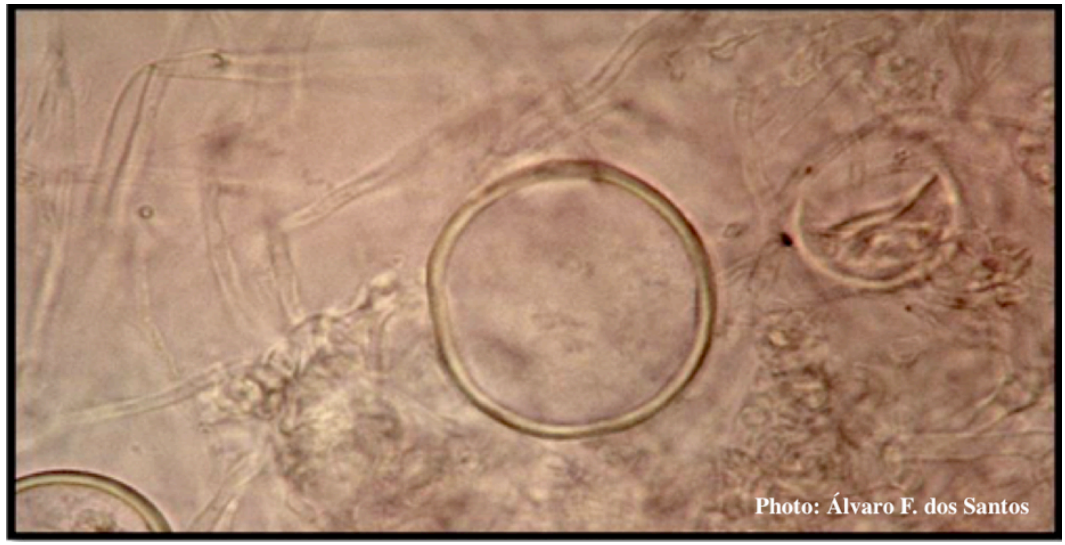

Figure 3. Globose chlamydospore. (reproduced with permission Summa Phytopathologica, courtesy A. F. dos Santos). 


\section{Genetics:}

Phytophthora boehmeriae is placed in Clade 10 (Kroon et al., 2012) (see also Fig. 4).

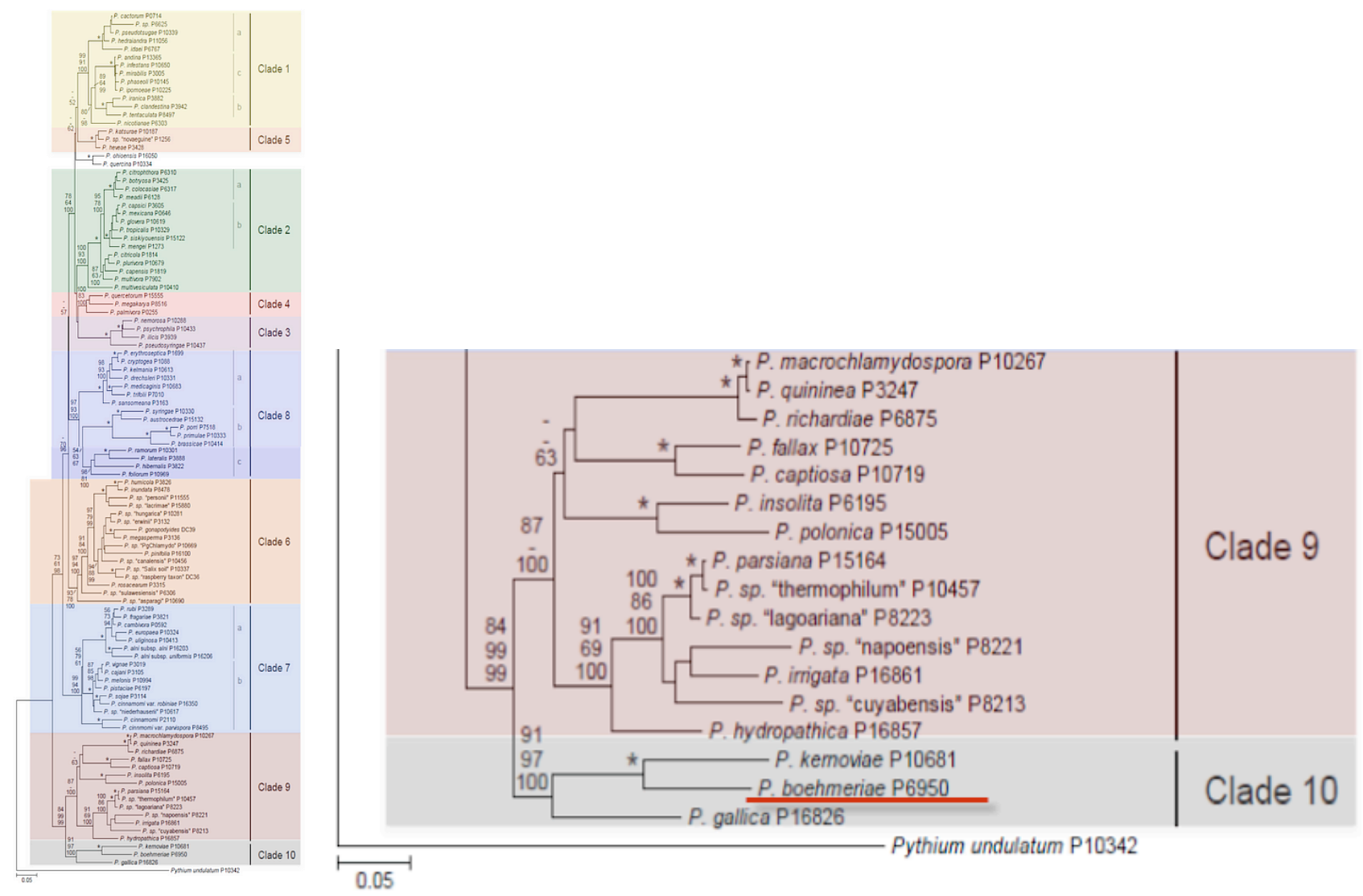

Figure 4. Genus-wide phylogeny for Phytophthora using four mitochondrial loci (cox2, nad9, rps10 and secY; 2,373 nucleotides). (Martin, Blair and Coffey, unpublished).

\section{Growth in culture:}

In carrot-agar cultures, $P$. boehmeriae has a petaloid appearance with maximum mycelial growth at $24^{\circ} \mathrm{C}$, and no growth at $32^{\circ} \mathrm{C}$ (Santos et al. 2006).

\section{Distinguishing characteristics for identification}

Phytophthora boehmeriae is distinguished from the other species that cause gummosis (P. nicotianae and $P$. frigida) especially by being homothallic and producing caducous sporangia with short pedicels $(<5 \mu \mathrm{m})$, and showing no growth at $32^{\circ} \mathrm{C}$ (Santos et al. 2006). The species $P$. meadii does not occur in Brazil, and differs from $P$. boehmeriae in the production of caducous sporangia on medium-length pedicels $(18 \mu \mathrm{m})$ and being heterothallic (Gallegly and Hong 2008).

\section{Disease History}

Gummosis has occurred in black wattle plantations in Brazil for more than 40 years (Santos and Luz 2007). The etiology was resolved only recently, with the causal agents identified as Phytophthora nicotianae (Santos et al. 2005), P. boehmeriae (Santos et al. 2006) and P. frigida (Alves et al. 2016). In South Africa, this disease has been reported in black wattle by Zeiljemaker (1971) associated with $P$. nicotianae and by Roux and Wingfield (1997) associated with P. boehmeriae and P. meadii. 


\section{Impacts in the forest}

Gummosis by $P$. boehmeriae has a limited geographical distribution in black wattle production areas of the state of Rio Grande do Sul, in southern Brazil (Santos and Luz 2007) and South Africa.

\section{Forest and Wildland Hosts and Symptoms:}

Gummosis caused by $P$. boehmeriae occurs in outbreaks in rainy years associated with strong and constant winds (Santos and Luz 2007). Black wattle plantations of Brazilian trees with gummosis caused by $P$. boehmeriae can be distinguished from those caused by $P$. frigida and P. nicotianae (Santos 2001, Santos and Luz 2007, Alves et al. 2016). Gummosis associated with P. frigida and $P$. nicotianae has lesions in the basal region of the trunk and does not exceed $1.5 \mathrm{~m}$ in height, while gummosis associated with $P$. boehmeriae produces lesions over the entire trunk reaching up to $10 \mathrm{~m}$ (Fig. 5).

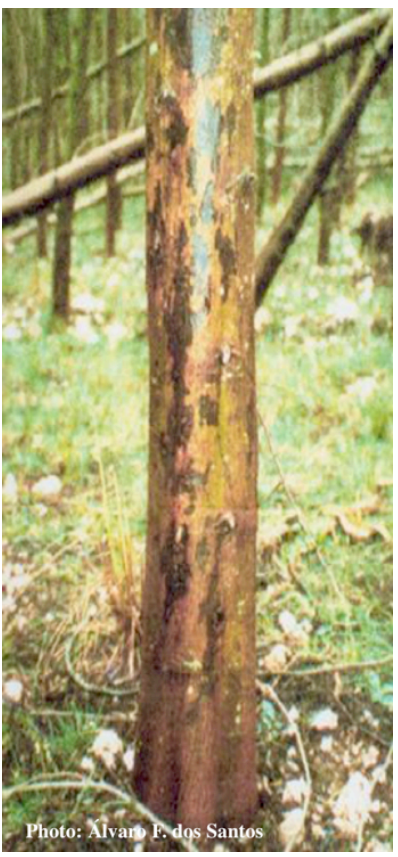

Fig. 5. Symptoms of gummosis on black wattle (reproduced with permission Summa Phytopathologica and Tropical Plant Pathology, courtesy A. F. dos Santos).

Table 1. Phytophthora boehmeriae main hosts, symptoms, and locations.

\begin{tabular}{|c|c|c|c|c|}
\hline Host Latin name & $\begin{array}{l}\text { Host common } \\
\text { name }\end{array}$ & Symptoms & Habitat & Region \\
\hline Acacia mearnsii & black wattle & gummosis, canker & plantations & South Africa, Brazil \\
\hline Boehmeria nivea & $\begin{array}{l}\text { Chinese grass; } \\
\text { white ramie }\end{array}$ & leaf blight & agriculture & $\begin{array}{l}\text { Taiwan, Japan, China, } \\
\text { Australia, Greece, South } \\
\text { Africa }\end{array}$ \\
\hline Broussonetia papyrifera & paper mulberry & leaf blight & & China \\
\hline Cedrus deodara & deodar cedar & & & China \\
\hline Citrus spp. & citrus & brown rot (fruit) & agriculture & Argentina, Australia, China \\
\hline Eucalyptus pilularis & blackbutt & root rot & & Australia \\
\hline Gossypium hirsutum & cotton & leaf blight, root rot & agriculture & China, Greece \\
\hline Pinus patula & $\begin{array}{l}\text { Mexican yellow } \\
\text { pine }\end{array}$ & root rot & plantations & Australia \\
\hline
\end{tabular}


Forest Phytophthoras 6(1). P. boehmeriae

\section{Management and education resources}

Forest Phytophthoras - a hidden threat to take a serious note of:

http://www.fabinet.up.ac.za/newsitem/240-forest Phytophthoras.pdf

Gomose de Phytophthora da acácia-negra:

http://forestphytophthoras.org/sites/default/files/educational materials/com tec101.pdf

O complexo gomose da acácia-negra:

http://forestphytophthoras.org/sites/default/files/educational materials/circ-tec44.pdf

\section{References}

Alves, T. C. A., Tessmann, D. J., Ivors, K. L., Ristaino, J. B. and Santos, A. F. dos. 2016. First report of gummosis caused by Phytophthora frigida on black wattle in Brazil. Plant Disease [Internet]. 100(11):2336 - 2336.

http://dx.doi.org/10.1094/PDIS-01-16-0134-PDN

Erwin DC, Ribeiro OK. 1996. Phytophthora diseases worldwide. St. Paul, MN, USA: APS Press. 562 p.

Frezzi MJ. 1950. Las especies de Phytophthora en la Argentina. Revista de Investigaciones Agrícolas 4: 47-133.

Gallegly, M. E. and Hong, C. 2008. Phytophthora - identifying species by morphology and DNA fingerprints. St. Paul, MN, USA: APS Press. 158 p.

Kroon, L. P.N. M., Brouwer, H., Cock, A. W. A. M. and Govers, F. 2012. The Genus Phytophthora Anno 2012. Phytopathology 102: 348-364. http://apsjournals.apsnet.org/doi/abs/10.1094/PHYTO-01-11-0025

Roux, J. and Wingfield, M. J. 1997. Survey and virulence of fungi occurring on diseased Acacia mearnsii in South-Africa. Forest Ecology and Management 99: 327- 336. http://dx.doi.org/10.1016/s0378-1127(97)00110-2

Santos, A. F. dos. 2001. Comportamento diferenciado da gomose de Phytophthora em diferentes alturas ao longo de troncos de acácia-negra (Acacia mearnsii) em Piratini, RS. Boletim de Pesquisa Florestal 43: 145.-149.

http://ainfo.cnptia.embrapa.br/digital/bitstream/CNPF-2009-09/30242/1/santos.pdf

Santos, A. F. dos and Luz, E. D. M. N. . 2007. A gomose da acácia-negra no Brasil: uma revisão. Summa Phytopathologica 33: 113-118. https://doi.org/10.1590/s0100-54052007000200002

Santos, A. F. dos, Luz, E. D. M. N. and Souza, J. T. 2005. Phytophthora nicotianae: agente etiológico da gomose da acácia-negra no Brasil. Fitopatologia Brasileira (Impresso) (Cessou em 2007. Cont. ISSN 1982-5676 Tropical Plant Pathology (Impresso) 30: 81-84. https://doi.org/10.1590/s0100-41582005000100015

Santos, A. F. dos, Luz, E. D. M. N. and Souza, J. T. 2006. First report of Phytophthora boehmeriae on black wattle in Brazil. Plant Pathology 55: 813-813. http://onlinelibrary.wiley.com/doi/10.1111/i.1365-3059.2006.01462.x/full

Zeiljemaker, F. C. J. 1971. Black-butt disease of black wattle caused by Phytophthora nicotianae var. parasitica. Phytopathology 61: 144-145.

http://www.apsnet.org/publications/phytopathology/backissues/Documents/1971Articles/Phyto61n02_144.PDF 